\title{
PENGEMBANGAN TEKS ANEKDOT SEBAGAI BAHAN AJAR SISWA KELAS X MAN PEMATANGSIANTAR
}

\section{THE DEVELOPMENT OF ANECDOTE TEXT FOR TEACHING MATERIALS IN GRADE X STUDENTS MAN PEMATANGSIANTAR}

\author{
Tri Wahyuni Lubis ${ }^{1 *}$, Sri Gusmiati ${ }^{2}$, Ikhwanuddin Nasution ${ }^{3}$ \\ Program Pascasarjana Bahasa Indonesia, Universitas Muslim Nusantara Alwashliyah \\ Medan, Indonesia ${ }^{1,2}$, Universitas Sumatera Utara, Indonesia ${ }^{3}$ \\ triwahyunilubis03@gmail.com ${ }^{1}$, srigusmiyati@gmail.com ${ }^{2}$, \\ ikhwanuddin25@gmail.com ${ }^{3}$ \\ *penulis korespondensi
}

\begin{tabular}{ll}
\hline Info Artikel & ABSTRAK \\
\hline Sejarah artikel: & Penelitian ini bertujuan untuk mengetahui pengembangan teks anekdot \\
Diterima: & berdasarkan struktur narasi sebagai bahan ajar pada siswa kelas X MAN \\
6 November 2019 & Pematangsiantar. Penelitian ini menggunakan metode R\&D. Subjek \\
Direvisi: & penelitian ini adalah siswa kelas X MAN Pematangsiantar. Langkah- \\
18 Desember 2019 & langkah yang digunakan dalam penelitian ini adalah merekontruksi teks \\
Disetujui: & anekdot menjadi karangan narasi sesuai dengan struktur, menyeleksi \\
14 Januari 2020 & karangan narasi berdasarkan struktur narasi karya siswa, merevisi beberapa \\
& karangan narasi menjadi antologi narasi, dan validasi para ahli. Berdasarkan \\
Kata kunci: & uji keefektifan materi, bahan ajar efektif 88,9\% dengan kategori sangat baik. \\
pengembangan, & Dari beberapa hasil karangan narasi karya siswa, peneliti mengambil sampel \\
anekdot, narasi, & untuk dijadikan sebuah antologi sebagai bahan ajar siswa. Dari hasil para \\
antologi & ahli, kelayakan isi dapat mendapatkan persentase sebesar 82,5\% dengan \\
& kategori sangat baik, penyajian pembelajaran mendapatkan persentase \\
& sebesar 90\% dengan kategori sangat baik, dan kebahasaan pembelajaran \\
& mendapatkan persentase 80\% dengan kategori baik. Dari hasil validasi \\
& tersebut antologi pengembangan teks anekdot menjadi karangan narasi \\
dapat dikatakan layak digunakan sebagai bahan ajar.
\end{tabular}

\begin{tabular}{|c|c|}
\hline Article Info & ABSTRACT \\
\hline $\begin{array}{l}\text { Article history: } \\
\text { Received: } \\
\text { 6 November } 2019 \\
\text { Revised: } \\
\text { 18 December } 2019 \\
\text { Accepted: } \\
\text { 14 January } 2020 \\
\\
\text { Keywords: } \\
\text { development, } \\
\text { anecdote, narrative, } \\
\text { anthology }\end{array}$ & $\begin{array}{l}\text { The objective of the research was to determine the development of anecdote } \\
\text { text based on the narrative structure as teaching material on grade X MAN } \\
\text { Pematangsiantar. This research applied R\&D method. The subject chosen } \\
\text { was grade X MAN Pematangsiantar. There were some stages carried out, } \\
\text { namely; reconstructing anecdote text to narrative essay in accordance with } \\
\text { the structure, selecting narrative essays based on the narrative structure in } \\
\text { students' work, revising some narrative essays to be narrative anthologies, } \\
\text { and validating by experts. Based on the effectiveness of the material test, it } \\
\text { showed that effectiveness was } 88.9 \% \text { with very good category. Then, from } \\
\text { students' written narrative work, the researcher selected samples to be used } \\
\text { as a students anthologies and used as students teaching materials. From } \\
\text { experts validation, the worthiness of validity was } 82,5 \% \text { with a very good } \\
\text { category, presentation of learning reached } 90 \% \text { with a very good category, } \\
\text { and language learning gets a percentage of } 80 \% \text { with a good category. Based } \\
\text { on the validation, the development of anecdote text as a narrative text can } \\
\text { be used as teaching material. }\end{array}$ \\
\hline
\end{tabular}




\section{PENDAHULUAN}

Keberadaan buku paket Bahasa Indonesia yang diterbitkan oleh pemerintah (Kemendikbud) baik untuk buku pegangan guru maupun buku pegangan siswa sebagai sarana penunjang belum maksimal untuk memfasilitasi pembelajaran. Dalam mengimplementasikan kurikulum 2013, guru masih kebingungan dikarenakan isi buku paket Bahasa Indonesia belum mendeskripsikan secara komprehensif isi silabus.

Secara teoretis, semestinya buku paket bahasa Indonesia untuk pegangan pendidik maupun pegangan peserta didik sudah dirancang sedemikian rupa sehingga standardisasi buku paket tersebut sudah dilakukan dengan pertimbangan standar isi. Standar isi mencakup beberapa hal, antara lain isi buku relevan dengan kurikulum mata pelajaran Bahasa Indonesia dan bahan yang ditulis dalam buku paket relevan dengan silabus yang telah ditetapkan oleh kemendikbud (Kristiantari, 2015:468).

Realita yang dijumpai di sekolah saat ini, isi buku paket yang berkenaan dengan materi ajar anekdot kurang relevan, karena belum maksimal mendeskripsikan indikator pencapaian kompetensi secara rinci sesuai tuntunan kompetensi dasar. Penyebabnya, dikarenakan buku paket terlebih dahulu disusun dibanding silabusnya. Dengan diberlakukannya kurikulum 2013 telah terjadi pergeseran yang signifikan dalam pendekatan pembelajaran Bahasa Indonesia, yaitu dari pendekatan komunikatif ke pendekatan teks (genre). Teks-teks yang terdapat dalam kegiatan pembelaran harus dipelajari secara sistematis, baik lisan maupun secara tertulis.
Mulyasa (2013:96) mengatakan bahwa bahan ajar merupakan salah satu bagian dari sumber ajar yang mengandung pesan pembelajaran, baik yang bersifat khusus maupun yang bersifat umum yang dapat dimanfaatkan untuk kepentingan pembelajaran.

Ahmadi (1990:1) mengatakan karangan dapat diartikan sebagai untaian kata-kata atau kalimat. Karangan juga dipandang sebagai suatu kegiatan komunikatif antara penulis dan pembaca berdasarkan teks yang telah dihasilkan. Keraf (2010:2), mengatakan karangan merupakan bahasa tulis dari rangkaian kata demi kata, sehingga menjadi sebuah kalimat, paragraf, dan akhirnya menjadi sebuah wacana yang dibaca dan dipahami. Selanjutnya Gie (1995) mengatakan bahwa karangan adalah hasil perwujudan gagasan dalam bahasa tulis yang dapat dibaca dan dipahami oleh pembaca. Keraf (2010:137) mengatakan bahwa narasi merupakan suatu bentuk wacana yang berusaha menceritakan suatu kejadian seolaholah pembaca melihat atau mengalami sendiri peristiwa itu.

Menurut Wijana (1995:24), teks anekdot adalah teks atau wacana yang berisikan humor untuk menyindir, becanda gurau, atau mengkritik secara tidak langsung segala macam kepincangan atau ketidakbenaran yang terjadi di kalangan masyarakat penciptanya. Sementara dalam KBBI (2008:62), anekdot diartikan sebagai sebuah cerita singkat yang menarik karena lucu dan mengesankan, biasanya mengenai orang-orang penting atau terkenal dan berdasarkan kejadian yang sebenarnya. Menurut Keraf (2010:42), anekdot adalah semacam cerita pendek yang bertujuan menyampaikan karakteristik yang 
menarik atau aneh mengenai seseorang atau hal lain.

Selanjutnya, menurut Kosasih (2013:14), langkah-langkah menulis teks anekdot yaitu menentukan topik, merumuskan tujuan, menghadirkan tokoh dan latar, melengkapi struktur, memerhatikan ketepatan penggunaan bahasa, dan mencantumkan judul yang sesuai dengan isi anekdot. Berdasarkan ciri-ciri kebahasaan, menurut Kosasih (2013:9) anekdot tergolong kedalam teks bergenre cerita. Ada enam ciri kebahasaan yang menonjol, yaitu: menggunakan kalimat langsung, menggunakan nama tokoh orang ketiga tunggal, menggunakan keterangan waktu, menggunakan kata kerja material, menggunakan kata konjungsi temporal, dan menggunakan konjungsi penerang atau penjelas. Kaidah penulisan teks anekdotmenggunakan pertanyaan retorika, menggunakan konjungsi waktu, menggunakan kata kerja, menggunakan kalimat perintah (Kemendikbud, 2013:112). Penulisan teks anekdot menurut Pardiyono (2007:292) bertujuan komunikatif, struktur retorik, kaidah kebahasaan dengan kalimat deklaratif. Menurut Chaer dan Agustina (2010:50), kalimat deklaratif, isinya hanya meminta pendengar atau yang mendengar kalimat itu untuk menaruh perhatian saja.

Pengampu mata pelajaran Bahasa Indonesia di kelas X MAN Pematangsiantar pada tahun pembelajaran 2018-2019 mengungkapkan bahwa isi buku paket Bahasa Indonesia kurang jelas mendeskripsikan materi pembelajaran tentang anekdot, sehingga memengaruhi nilai kreteria ketuntasan minimal (KKM) siswa. Di sisi lain, keberadaan konsep serta pengembangan pembelajaran berbasis teks belum begitu jelas bagi guru.

Berdasarkan hasil pengamatan yang dilakukan peneliti, siswa kelas $\mathrm{X}$ MAN Pematangsiantar tahun pelajaran 2018/2019 kesulitan dalam pembelajaran memproduksi teks anekdot (menulis karangan anekdot). Sebagian besar siswa kesulitan dalam menuliskan struktur generik dan ciriciri serta kaidah kebahasaan teks anekdot. Oleh sebab itu, peneliti melakukan penelitian mengenai permasalahan yang dihadapi siswa tersebut.

Penelitian ini adalah berupa pengembangan bahan pembelajaran dalam bentuk modul yang berisikan tentang mendeskripsikan struktur generik dan ciri-ciri dari anekdot berdasarkan kurikulum 2013. Adapun tujuan penelitian ini adalah mendeskripsikan teks anekdot menjadi karangan narasi. Mendeskripsikan validasi pengembangan bahan ajar anekdot terhadap penulisan karangan narasi. Di mana hipotesis awalnya, yaitu pengembangan bahan ajar anekdot berdasarkan struktur generik dan ciri-cirinya dapat meningkatkan kemampuan menulis karangan anekdot.

\section{METODE}

Penelitian yang digunakan dalam penelitian ini adalah penelitian pengembangan yang menghasilkan produk berupa media pembelajaran yang dalam hal ini berbentuk modul pembelajaran. Metode penelitian dan pengembangan merupakan metode penelitian yang digunakan untuk menghasilkan suatu produk tertentu dan menguji keefektifan produk tersebut Sugiyono (2013:297).

Metode penelitian dalam penelitian ini mengacu pada Four- $D$ Model. Menurut Thiagarajan (1974:6- 
9), model ini terdiri atas 4 tahap pengembangan yaitu pendefinisian, perancangan, pengembangan, dan penyebaran. Model pengembangan ini dapat dilakukan dengan memodifikasi sesuai dengan karakteristik subjek yang akan diteliti dalam batas-batas yang rasional. Di samping itu model yang akan diikuti juga dapat diinterpretasikan sesuai dengan kebutuhan pengembangan di lapangan dengan ketentuan tidak mengubah makna.

Instrumen pengumpulan data yang dipakai adalah lembar angket validasi tim ahli, lembar angket tanggapan siswa terhadap bahan ajar yang diperoleh dari uji coba lapangan terbatas, dan tes hasil belajar siswa.

Pengumpulan data menurut Arikunto (2006:222) merupakan pekerjaan yang penting dalam sebuah penelitian. Pengumpulan data yang benar akan mengahsilkankesimpulan yang benar. Oleh karena itu, kesalahan dalam mengumpulkan data akan memberikan kesimpulan yang salah.

Analisis data menggunakan teknik statistik deskriptif. Sugiyono (2013:254) mengatakan, statistik deskriptif digunakan untuk menganalisis data dengan cara mendeskripsikan atau menggambarkan data yang telah terkumpul sebagaimana adanya. Membuat kesimpulan yang berlaku untuk umum atau untuk generalisasi.

Angket validasi diberikan kepada validator dan uji coba lapangan terbatas dibuat dalam bentuk skala likert yang diberikan skor: sangat baik $(\mathrm{X}>5)$, baik $(3,1<\mathrm{X} \leq 4,2)$, cukup $(2,6<X \leq 2,9)$, kurang $(1,8<X \leq 2,5)$, dan sangat kurang $(<1,8)$. Skala likert digunakan untuk mengukur sikap, pendapat, dan persepsi seseorang atau sekelompok orang tentang fenomena sosial Sugiyono (2013:165).

\begin{tabular}{llr}
\multicolumn{2}{c}{ Kemudian data } & dianalisis \\
dengan menggunakan & statistik \\
deskriptif & (skor rata-rata & dengan
\end{tabular} persentasi), yaitu menghitung persentasi indikator penggunaan bahan ajar pengembangan anekdot berdasarkan struktur dalam teks anekdot. Persentasi skor ini dapat dihitung melalui rumus perhitungan.

\section{Persentase skor $=$ \\ $\frac{\text { Jumlah skor indikator per kategori }}{\text { Jumlah skor total kategori }} \times 100 \%$}

Perhitungan data hasil penelitian menggunakan rumus di atas akan menghasilkan angka dalam bentuk persen untuk melihat persentasi kelayakan media. Dengan kriteria penilaian sangat baik $(81 \% \leq x \leq 100 \%)$, baik $\quad(61 \% \leq x \leq 80 \%), \quad$ sedang $(41 \% \leq x \leq 60 \%)$, kurang baik $(21 \% \leq x \leq 40 \%)$, dan sangat kurang baik $(0 \% \leq x \leq 20 \%)$.

\section{HASIL DAN PEMBAHASAN}

Pengambilan data dengan teknik tes teks anekdot pada peserta didik kelas X MAN Pematangsiantar. Tes ini diberikan sebagai langkah awal (Pre-Tes) untuk mengetahui keterampilan peserta didik dalam menulis teks anekdot sebelum dilakukan pengembangan bahan ajar. Untuk mengetahui efektifitas pengembangan bahan ajar menulis teks anekdot pada peserta didik kelas $\mathrm{X}$ MAN Pematangsiantar, data berfokus pada hasil angket kebutuhan peserta didik dan hasil tes menulis teks anekdot. Berdasarkan data yang diperoleh peneliti, kemudian akan dikembangkan modul yang sesuai dengan kebutuhan dan kondisi peserta didik. Pengembangan modul yang dilakukan oleh peneliti diharapkan 
mampu meningkatkan keterampilan menulis teks anekdot peserta didik. Kemudian, dilihat dari hasil tes menulis tes anekdot sebelum dilakukan pengembangan bahan ajar teks anekdot yaitu 59,9 yang berada pada kategori cukup. Setelah dilakukan pengembangan bahan ajar menulis teks anekdot yaitu sebesar 88,9 yang berada pada kategori sangat baik. Dari hasil tersebut,terlihat bahwa pengembangan bahan ajar menulis teks anekdot efektif dalam meningkatkan keterampilan menulis teks anekdot oleh peserta didik kelas X MAN Pematangsiantar.

$$
\text { Keefektifan bahan ajar }
$$
merupakan kegiatan untuk melihat sejauh manapengaruh produk yang telah dihasilkaan untuk meningkatkan kemampuan siswa dalam menulis teks anekdot. Berdasarkan hal tersebut maka dilakukan pretest dan postest yakni pembelajaran sebelum menggunakan produk dan sesudah menggunakan produk. Berikut ini akan disajikan hasil rekapitulasi data hasil belajar siswa yang diperoleh dari pre-test dan postest yang berjumlah 20 orang.

Hasil data dengan teknik tes teks anekdot pada peserta didik kelas $\mathrm{X}$ MAN Pematangsiantar, adalah seperti tabel berikut.

Tabel 1. Hasil Pre Test Teks Anekdot

\begin{tabular}{|c|l|c|c|c|c|c|c|c|}
\hline \multirow{2}{*}{ No } & \multirow{2}{*}{$\begin{array}{c}\text { Kode } \\
\text { Siswa }\end{array}$} & $\begin{array}{c}\text { Abstrak } \\
\mathbf{1 0}\end{array}$ & $\begin{array}{c}\text { Orientasi } \\
\mathbf{2 0}\end{array}$ & $\begin{array}{c}\text { Komplikasi } \\
\mathbf{2 0}\end{array}$ & $\begin{array}{c}\text { Evaluasi } \\
\mathbf{2 0}\end{array}$ & $\begin{array}{c}\text { Resolusi } \\
\mathbf{1 5}\end{array}$ & $\begin{array}{c}\text { Koda } \\
\mathbf{1 5}\end{array}$ & $\mathbf{1 0 0}$ \\
\hline 1 & S1 & 5 & 10 & 10 & 9 & 8 & 9 & 51 \\
\hline 2 & S2 & 5 & 13 & 15 & 16 & 9 & 8 & 66 \\
\hline 3 & S3 & 7 & 10 & 10 & 15 & 8 & 6 & 56 \\
\hline 4 & S4 & 6 & 10 & 16 & 15 & 9 & 10 & 66 \\
\hline 5 & S5 & 5 & 15 & 10 & 10 & 9 & 8 & 57 \\
\hline 6 & S6 & 5 & 10 & 9 & 10 & 9 & 7 & 50 \\
\hline 7 & S7 & 4 & 12 & 10 & 10 & 7 & 7 & 50 \\
\hline 8 & S8 & 6 & 10 & 15 & 15 & 5 & 6 & 57 \\
\hline 9 & S9 & 6 & 10 & 10 & 9 & 8 & 7 & 50 \\
\hline 10 & S10 & 4 & 14 & 10 & 18 & 9 & 6 & 61 \\
\hline 11 & S11 & 5 & 12 & 15 & 15 & 10 & 8 & 65 \\
\hline 12 & S12 & 5 & 10 & 9 & 15 & 10 & 9 & 58 \\
\hline 13 & S13 & 7 & 18 & 8 & 8 & 10 & 5 & 56 \\
\hline 14 & S14 & 6 & 16 & 15 & 10 & 9 & 7 & 63 \\
\hline 15 & S15 & 7 & 10 & 9 & 17 & 7 & 10 & 60 \\
\hline 16 & S16 & 5 & 17 & 14 & 8 & 8 & 9 & 61 \\
\hline 17 & S17 & 5 & 16 & 17 & 10 & 8 & 9 & 65 \\
\hline 18 & S18 & 6 & 18 & 18 & 19 & 6 & 8 & 75 \\
\hline 19 & S19 & 6 & 15 & 16 & 16 & 7 & 9 & 69 \\
\hline 20 & S20 & 5 & 15 & 10 & 18 & 7 & 7 & 62 \\
\hline & & & Jumlahyyyyyyyyyyyyyyy \\
\hline
\end{tabular}


Berdasarkan hasil menulis teks anekdot peserta didik, diperoleh bahwa nilai terendah adalah 50 dan nilai tertinggi adalah 75 dengan nilai ratarata secara keseluruhan sebesar 1198. Apabila nilai rata rata tersebut dikonsultasikan dengan kriteria penilaian, maka nilai rata-rata 59,9 berada pada kriteria cukup. Dengan demikian, disimpulkan bahwa menulis teks anekdot peserta didik kelas $\mathrm{X}$ MAN Pematangsiantar berada pada kategori cukup dengan nilai rata rata di bawah KKM 80.

Pada hasil analisis pengembangan teks anekdot menjadi karangan narasi berdasarkan strukturnya menggunakan bahan ajar terdapat perbandingan yang cukup signifikan. Dari hasil yang tidak menggunakan bahan ajar 59,9\% dengan hasil yang menggunakan bahan ajar menjadi $88,9 \%$ dengan kriteria sangat baik. Berikut tabel hasil pos-tes.

Tabel 2. Hasil Pos Test Teks Anekdot Menjadi Karangan Narasi Menggunakan Bahan Ajar

\begin{tabular}{|c|l|c|c|c|c|c|c|c|}
\hline \multirow{2}{*}{ No } & $\begin{array}{l}\text { Kode } \\
\text { Siswa }\end{array}$ & $\begin{array}{c}\text { Abstrak } \\
\mathbf{1 0}\end{array}$ & $\begin{array}{c}\text { Orientasi } \\
\mathbf{2 0}\end{array}$ & $\begin{array}{c}\text { Komplikasi } \\
\mathbf{2 0}\end{array}$ & $\begin{array}{c}\text { Evaluasi } \\
\mathbf{2 0}\end{array}$ & $\begin{array}{c}\text { Resolusi } \\
\mathbf{1 5}\end{array}$ & $\begin{array}{c}\text { Koda } \\
\mathbf{1 5}\end{array}$ & $\mathbf{1 0 0}$ \\
\hline 1 & S1 & 9 & 17 & 19 & 19 & 13 & 13 & 90 \\
\hline 2 & S2 & 8 & 18 & 19 & 18 & 14 & 13 & 90 \\
\hline 3 & S3 & 9 & 18 & 18 & 18 & 14 & 13 & 90 \\
\hline 4 & S4 & 9 & 19 & 19 & 19 & 13 & 13 & 92 \\
\hline 5 & S5 & 9 & 19 & 18 & 18 & 12 & 14 & 90 \\
\hline 6 & S6 & 8 & 18 & 18 & 18 & 12 & 14 & 88 \\
\hline 7 & S7 & 9 & 19 & 17 & 18 & 13 & 12 & 88 \\
\hline 8 & S8 & 8 & 18 & 17 & 19 & 13 & 13 & 88 \\
\hline 9 & S9 & 8 & 19 & 18 & 19 & 13 & 12 & 89 \\
\hline 10 & S10 & 8 & 19 & 17 & 18 & 14 & 12 & 88 \\
\hline 11 & S11 & 9 & 19 & 18 & 19 & 13 & 12 & 90 \\
\hline 12 & S12 & 8 & 18 & 18 & 17 & 12 & 13 & 86 \\
\hline 13 & S13 & 9 & 18 & 19 & 17 & 13 & 14 & 90 \\
\hline 14 & S14 & 8 & 18 & 19 & 18 & 12 & 12 & 87 \\
\hline 15 & S15 & 8 & 19 & 18 & 17 & 12 & 12 & 86 \\
\hline 16 & S16 & 9 & 18 & 18 & 19 & 12 & 13 & 89 \\
\hline 17 & S17 & 9 & 18 & 18 & 19 & 13 & 13 & 90 \\
\hline 18 & S18 & 9 & 18 & 18 & 19 & 13 & 12 & 89 \\
\hline 19 & S19 & 9 & 18 & 19 & 17 & 14 & 12 & 89 \\
\hline 20 & S20 & 8 & 19 & 19 & 18 & 13 & 12 & 89 \\
\hline & & & Jumlah & & & & 1778 \\
\hline
\end{tabular}

Ada 10 teks yang dari teks narasi diubah menjadi teks anekdot, yaitu: Kesetrika, Menyindir Koruptor, Empat Kali Tujuh, Penjual Roti, Kereta dan Tukang Kupat Tahu, Sekolah
Bertaraf Internasional, Nasib Maling Sandal, Muka Tong Sampah, Apakah Ibu Sudah Pernah Keliling Dunia? Kotak Pensil Mahal, dan Kakek Jangan Duduk di Luar. 
Selanjutnya 7 teks anekdot yang diubah menjadi teks narasi, yaitu: Cara Diet Paling Ampuh, Makan Rumput, Bapak Kasih Makan Apa? Sudah Terang, Kursi Lupa, Cinta Itu Tidak Adil, dan Sedekah.

Validasi ahli materi terhadap pengembangan teks anekdot menjadi karangan narasi berdasarkan struktur narasi dilakukan oleh dua orang ahli materi yaitu dosen program pascasarjana Universitas Muslim Nusantara Al-Washliyah Medan dan guru bidang studi Bahasa Indonesia Kelas $\mathrm{X}$ MAN Pematangsiantar.

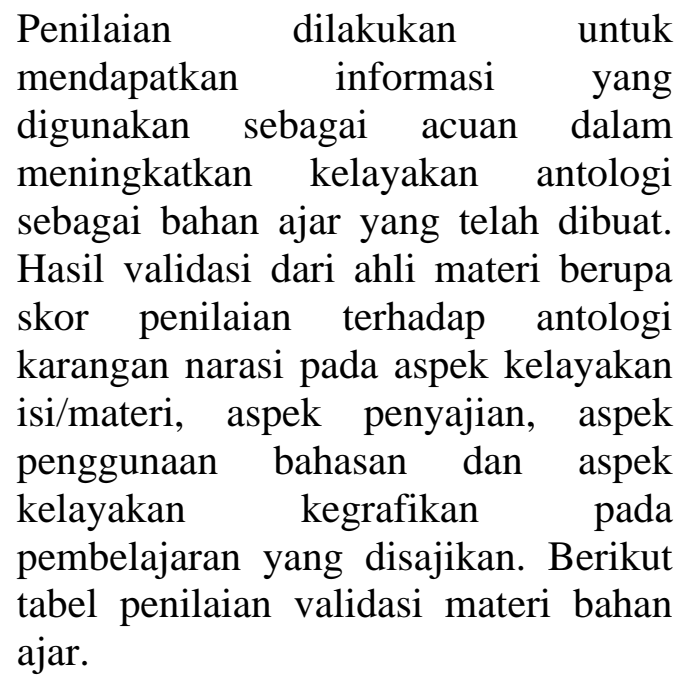

Tabel 3. Hasil ValidasiMateri Bahan Ajar Anekdot (Kelayakanisi/materi)

\begin{tabular}{|c|c|c|c|c|c|}
\hline \multirow{2}{*}{ Indikator } & \multicolumn{5}{|c|}{ Skor } \\
\hline & 5 & 4 & 3 & 2 & 1 \\
\hline $\begin{array}{l}\text { 1. Materi memuat materi pokok bahasan yang } \\
\text { mendukung tercapainya KI dan KD }\end{array}$ & & & $\sqrt{ }$ & & \\
\hline $\begin{array}{l}\text { 2. Konsep, definisi, prinsip, prosedur, contoh, dan } \\
\text { pelatihan pada modul sesuai dengan materi pokok yang } \\
\text { mendukung tercapainya KI dan KD }\end{array}$ & & & $\sqrt{ }$ & & \\
\hline $\begin{array}{l}\text { 3. Materi dalam modul membuatsiswa mengenali tema, } \\
\text { mengidentifikasi dan menjelaskan isi, mengonstruksi } \\
\text { pengetahuan baru dan menerapkan pengetahuan sesuai } \\
\text { KI dan KD. }\end{array}$ & & & $\sqrt{ }$ & & \\
\hline $\begin{array}{l}\text { 4. Modul akurat dan dirumuskan dengan tepat sehingga } \\
\text { mendukung tercapainya KI } 3.5 \text { dan KI } 3.6 \text { serta KD } 3 \text {. } \\
\text { 51, 3.52. }\end{array}$ & & & $\sqrt{ }$ & & \\
\hline $\begin{array}{l}\text { 5. Modul dirumuskan secara akurat sehingga tidak } \\
\text { menimbulkan multitafsir bagi siswa. }\end{array}$ & & & $\sqrt{ }$ & & \\
\hline $\begin{array}{l}\text { 6. Anekdotdirumuskan susuai dengan KD } 3.5,3.6 \\
\text { sehingga siswa tidak melakukan kekeliruan sistematis. }\end{array}$ & & & $\sqrt{ }$ & & \\
\hline $\begin{array}{l}\text { 7. Materi anekdot memuat contoh, fakta, ilustrasi secara } \\
\text { akurat mengenaikonsep dan prinsip. }\end{array}$ & & $\sqrt{ }$ & & & \\
\hline $\begin{array}{l}\text { 8. Soal yang disajikan secara akurat, sehingga siswa dapat } \\
\text { menguasai materi. }\end{array}$ & & $\sqrt{ }$ & & & \\
\hline $\begin{array}{l}\text { 9. Materi yang disajikan sesuai dengan perkembangan } \\
\text { ilmu dan teknologi saat ini. }\end{array}$ & & $\sqrt{1}$ & & & \\
\hline 10.Fitur yang disajikan bersifat kekinian (up to date). & & $\sqrt{ }$ & & & \\
\hline $\begin{array}{l}\text { 11. Materi yang disajikan dapat mendorong siswa secara } \\
\text { runtut membuat kesimpulan yang sahih (valid). }\end{array}$ & & $\sqrt{ }$ & & & \\
\hline
\end{tabular}




\begin{tabular}{|c|c|c|c|c|c|}
\hline \multirow{2}{*}{ Indikator } & \multicolumn{5}{|c|}{ Skor } \\
\hline & 5 & 4 & 3 & 2 & 1 \\
\hline $\begin{array}{l}\text { 12. Materi yang disajikan dapat menumbuhkan kreativitas } \\
\text { siswa. }\end{array}$ & $\sqrt{ }$ & & & & \\
\hline $\begin{array}{l}\text { 13. Materi yang dirumuskan memiliki keterkaitan antar } \\
\text { konsep. }\end{array}$ & & $\sqrt{ }$ & & & \\
\hline $\begin{array}{l}\text { 14. Materi yang disajikan bersifat komunikatif sehingga } \\
\text { dapat memperjelas keadaan atau masalah yang sedang } \\
\text { dipelajari. }\end{array}$ & & $\sqrt{ }$ & & & \\
\hline $\begin{array}{l}\text { 15. Materi memuat uraian, contoh, atau latihan dapat } \\
\text { menjelaskan penerapan suatu konsep dalam kehidupan } \\
\text { sehari-hari. }\end{array}$ & & $\sqrt{ }$ & & & \\
\hline $\begin{array}{l}\text { 16. Materi yang disajikan menarik sehingga dapat } \\
\text { menumbuhkan minat siswa untuk mengkaji atau } \\
\text { mempelajarinya lebih jauh. }\end{array}$ & $\sqrt{ }$ & & & & \\
\hline $\begin{array}{l}\text { 17. Tugas-tugas dalam modul dapat mendorong siswa } \\
\text { memperoleh informasi lebih lanjut dari berbagai } \\
\text { sumber. }\end{array}$ & & $\sqrt{ }$ & & & \\
\hline $\begin{array}{l}\text { 18. Modul dilengkapi dengan materi evaluasi yang dapat } \\
\text { mengukur kemampuan siswa. }\end{array}$ & & $\sqrt{ }$ & & & \\
\hline JUMLAH & 10 & 40 & 18 & & \\
\hline TOTAL & & 68 & & & \\
\hline Rata-rata & & 3 , & & & \\
\hline Kategori & & & & & \\
\hline
\end{tabular}

Berdasarkan perhitungan di atas, rerata nilai kelayakan isi/materi, kelayakan penyajian, kelayakan penggunaan bahasa, dan kelayakan kegrafikan adalah 3,7. Jika diintepretasi, nilai tersebut termasuk dalam kategori Baik.

Modul dengan teks anekdot ini dibuat mengacu pada Kompetensi Inti (KI 3). Kompetensi tersebut menurut Damayanti, dkk (2014:3) meliputi memahami, menerapkan, menganalisis pengetahuan faktual, konseptual, prosedural berdasarkan rasa ingin tahunya tentang ilmu pengetahuan, teknologi, seni, budaya, dan humaniora dengan wawasan kemanusiaan, kebangsaan, kenegaraan, dan peradaban terkait penyebab fenomena dan kejadian, serta menerapkan pengetahuan prosedural pada bidang kajian yang spesifik sesuai dengan bakat dan minatnya untuk memecahkan masalah. Selanjutnya, dalam KI 4 memuat mengolah, menalar, dan menyaji dalam ranah konkret dan ranah abstrak terkait dengan pengembangan dari yang dipelajarinya di sekolah secara mandiri, dan mampu menggunakan metoda sesuai kaidah keilmuan (Damayanti, dkk., 2014). Sementara itu, Kompetensi Dasar yang digunakan terdiri atas (3.5) mengevaluasi teks anekdot dari aspek makna tersirat; (4.5) mengonstruksi makna tersirat dalam sebuah teks anekdot; (3.6) menganalisis struktur dan kebahasaan teks anekdot; dan (4.6) menciptakan kembali teks anekdot 
dengan memerhatikan struktur, dan kebahasaan (Damayanti, dkk., 2014).

Alokasi waktu dalam kegiatan penelitian ini adalah $2 \times 45$ menit dan dilakukan dalam dua kali pertemuan. Tujuan utama disusunnya bahan ajar adalah untuk menyediakan bahan ajar yang sesuai dengan tuntutan kurikulum dengan mempertimbangkan kebutuhan peserta didik, yakni bahan ajar yang sesuai dengan karakteristik dan setting atau lingkungan sosial peserta didik. Membantu peserta didik dalam memperoleh alternatif bahan ajar disamping buku-buku teks yang terkadang sulit diperoleh. Memudahkan guru dalam melaksanakan pembelajaran.

\section{PENUTUP}

Berdasarkan hasil penelitian pengembangan teks anekdot menjadi karangan narasi berdasarkan struktur narasi yang dilakukan, maka dapat disimpulkan. Berdasarkan penilaian yang didapat siswa dalam menulis teks anekdot terdapat nilai terendah 50,belum memenuhi standart KKM. Perolehan rata-rata siswa 59,9 dengan kategori cukup.Penelitian yang dilakukan dengan menggunakan bahan ajar anekdot terhadap penulisan karangan pada siswa kelas X MAN Pematangsiantar dengan nilai rata-rata 88,9 pada kategori baik.

Berdasarkan hasil uji validasi kelayakan pengembangan bahan ajar anekdot terhadap penulisan karangan pada siswa kelas $\mathrm{X}$ MAN Pematangsiantar oleh dua tim ahli menilai bahwa persentase $3,6 \%$. Dengan demikian materi terhadap antologi pengembangan teks anekdot terhadap penulisan karangan siswa kelas $\mathrm{X}$ MAN Pematangsiantar dikatakan sudah layak oleh ahli materi pembelajaran.
Hasil temuan penelitian yang telah diuraikan, peneliti menyarankan agar lebih menerapkan pelajaran pengembangan teks anekdot menjadi karangan narasi berdasarkan struktur narasi, agar siswa lebih berpotensi dalam kegiatan tulis menulis.

\section{DAFTAR PUSTAKA}

Ahmadi, Mukhsin. (1990). Strategi Belajar Mengajar Ketrampilan Berbahasa dan Apresiasi Sastra. Malang: Asah Asih Asuh.

Arikunto, Suharsimi, (2006). Prosedur Suatu Pendekatan Praktik. Jakarta: Rineka Cipta.

Chaer, Abdul, dan Agustina. (2010). Sosiolinguistik Perkenalan Awal. Jakarta: Rineka Cipta.

Damayanti, N. K. A., Martha, I. N., Gunatama, G., \& Hum, M. (2014). Pembelajaran Menulis Teks Anekdot Berpendekatan Saintifik dengan Model Pembelajaran Berbasis Proyek (Project Based Learning) Pada Siswa Kelas X Tata Kecantikan Kulit 1 Di SMK Negeri 2 Singaraja. Jurnal Pendidikan Bahasa dan Sastra Indonesia Undiksha, 2 (1).

Gie, The Liang. (1995). Pengantar Dunia Karang Mengarang. Yogyakarta : Liberty.

KBBI, T. (2008). Kamus Besar Bahasa Indonesia. Jakarta: Pusat Bahasa.

Kemendikbud. (2013). Peraturan Menteri Pendidikan dan Kebudayaan, Nomor 81A, Tahun 2013, tentang Implementasi Kurikulum 
Pedoman Umum Pembelajaran. Jakarta: Kemendikbud.

Keraf, Gorys. (2010). Argumentasi dan Narasi. Jakarta: Gramedia.

Kosasih, Engkos. (2013). Cerdas Berbahasa Indonesia Untuk SMA/MA Kelas X. Bandung: Erlangga.

Kristiantari, M. R. (2015). Analisis kesiapan guru sekolah dasar dalam mengimplementasikan pembelajaran tematik integratif menyongsong kurikulum 2013.JPI (Jurnal Pendidikan Indonesia), 3(2).

Mulyasa, Enco. (2013). Pengembangan dan Implementasi Kurikulum 2013. Bandung: PT. Remaja Rosdakarya.

Pardiyono. (2007). Pasti Bisa! Teaching Genre-Based Writing. YogyakartaAndi Offset.
Setiadi, I., \& Imania, N. (2014). Pembelajaran Menulis Teks Anekdot Pada Siswa Kelas X SMA N 1 Metro Tahun Pelajaran 2013/2014.

Sugiyono. (2013). Metode Penelitian Kuantitatif dan Kualitatif dan $R \& D$. Bandung: Alfabeta.

Thiagarajan. (1974). Instructional Development for Training Teachers of Exceptional Children. Washinton DC: National Center for Improvement Educational System.

Wijana, I. (1995). Wacana kartun dalam Bahasa Indonesia (Doctoral dissertation, Universitas Gadjah Mada) 